\title{
The Effect of Java Langgam Music Therapy As Adjuvant Therapy Towards Changes Blood Pressure in Hypertension Patients in Puskesmas Depok II Sleman Yogyakarta
}

\author{
Eva Marti ${ }^{1}$, Arimbi Karunia Estri ${ }^{2}$, Margareta Hesti Rahayu ${ }^{3}$ \\ ${ }^{123}$ Lecturer of Stikes Panti Rapih Yogyakarta \\ Jl. Tantular 401 Yogyakarta \\ Email: evamarti85@gmail.com
}

\begin{abstract}
Abstrak
Prevalensi hipertensi di Kabupaten Sleman pada tahun 2015 adalah 33,2\%, di mana hipertensi berada di peringkat kedua dari sepuluh penyakit rawat jalan teratas di Puskesmas di Kabupaten Sleman. Hipertensi memerlukan perawatan teratur dan terus menerus untuk mencegah komplikasi lebih lanjut. Oleh karena itu, diperlukan terapi pelengkap sebagai adjuvan seperti terapi musik Jawa sebagai pilihan terapeutik. Musik Jawa Langgam adalah musik klasik yang telah dikenal luas oleh masyarakat Yogyakarta. Tujuan dari penelitian ini adalah untuk mengetahui pengaruh terapi musik gaya Jawa pada perubahan tekanan darah pada pasien hipertensi pada kelompok kontrol dan kelompok intervensi. Penelitian ini adalah penelitian eksperimental semu yang membandingkan perubahan tekanan darah pada kelompok intervensi dan kelompok kontrol. Sampel yang digunakan adalah pasien hipertensi yang secara rutin dirawat di Puskesmas Depok II, sebanyak 60 orang, 30 orang pada kelompok intervensi dan 30 orang pada kelompok kontrol. Hasil penelitian menunjukkan bahwa terdapat perbedaan tekanan darah sistolik dan dyastolik secara signifikan pada kelompok intervensi dibandingkan dengan kelompok kontrol dengan nilai $P=0,000(<0,05)$. Terapi musik Langgam Jawa dapat dipilih sebagai terapi tambahan untuk pasien hipertensi di DI Yogyakarta.
\end{abstract}

Kata kunci : Hipertensi, Terapi Adjuvant, Musik Gaya Jawa

Abstract
The prevalence of hypertension in Sleman Regency in 2015 was 33.2\%, where hypertension was ranked second from the top ten outpatient diseases in the Puskesmas in Sleman Regency. Hypertension requires regular and continuous treatment to prevent further complications. Therefore, it is necessary to have complementary therapies as adjuvants such as Javanese music therapy as a therapeutic choice. Langgam Javanese music is classical music that has been well known by the people in Yogyakarta. The purpose of this study was to determine the effect of Javanese style music therapy on changes in blood pressure in hypertension patients in the control group and intervention group. This study was a quasi-experimental study that compared changes in blood pressure in the intervention group and the control group. The sample used was hypertensive patients who routinely treated in Depok II Health Center, as many as 60 people, 30 people in the intervention group and 30 people in the control group. The results showed that there difference in systolic and dyastolic blood pressure significantly in the intervention group compared to the control group with a value of $P=0,000(<0.05)$. Langgam Jawa music therapy can be chosen as an adjuvant therapy for hypertensive patients in DI Yogyakarta.

Keywords : Hypertension, Adjuvant Therapy, Javanese Style Music 
Article info:

Article submitted on April 29, 2019

Articles revised on May 20, 2019

Articles received on June 27, 2019

DOI: http://dx.doi.org/10.21927/jnki.2019.7(2).86-95

\section{INTRODUCTION}

The prevalence of hypertension is predicted to continue to increase in both developed and developing countries. Based on data from basic health research in 2013, the prevalence of hypertension in Indonesia was $26.5 \%$ and the Special Region of Yogyakarta (DIY) ranked third in the prevalence of hypertension based on the diagnosis of health workers (14). The prevalence of hypertension in Sleman Regency, which is one of the regencies in the DIY Province in 2015 was $33.2 \%$, where hypertension was ranked second from the top ten of outpatient diseases in the Community Health Center (Puskesmas) in Sleman Regency.

The increase in the incidence of hypertension has a high risk in an increase in the number of complications such as cardiovascular disease, strokes and even lead to death. The increase in the incidence of hypertension is more prevalent at the age above 50 , this is based on research conducted by Manandhar, Roju, Sinha \& Humagain (2012) which showed that the incidence of hypertension at the age above 50 is as much as $44.9 \%$. Therefore, it is necessary to control blood pressure both pharmacologically and non-pharmacologically (11). According to the National Comitte Joint Guideline 8, pharmacological management and implementation for hypertensive patients is to provide ACE inhibitor classes, angiotensin receptor blockers, $\beta$ blockers, calcium channel blockers, thiazide type diuretics (4). However, special attention needs to be paid to the provision of pharmacological therapy in the elderly based on the prevalence of hypertension which is most prevalent in the elderly group
(12). The administration of pharmacological therapy in the elderly has side effects on kidney function so that the administration of antihypertensive drugs with low doses is recommended. Therefore, there is a need for complementary therapy as an adjuvant of phamacological therapy to help control blood pressure so as to increase the effectiveness of primary therapy, reduce the risk of hypertensive complications and reduce discomfort due to side effects of antihypertensive drugs. (12).

Based on a systematic review, it was found that one of the interventions of several adjuvant therapies recommended for hypertensive patients and has proven useful in some of the results of the research is the provision of music therapy (9). Music therapy is an intervention that is often used because music therapy is an easy therapy to do. In addition, there is no need for special preparation and can be practiced at any time and easily accepted by the general public (15). Music therapy is recommended as an independent nursing intervention because music therapy is simple and easy to apply by nurses in providing independent nursing care (13).

Music therapy has a positive effect because its working mechanism influences the nervous system and stress hormones such as cortisol. This is supported by the results of research conducted by Liu and Ptrrini (2015) which showed that patients experienced a decrease in cortisol levels after being given music therapy during surgery. A similar research was also conducted by Siritunga, Wijewardena, Ekanayaka \& Mudunkotuwa (2013). The results showed that respondents who were given 22 minutes of music therapy had a decrease in systolic and diastolic 
blood pressure, as well as a decrease in heart rate and respiratory rate.

Classical music has proven to be beneficial for health, but this classical music still sounds foreign to the people of Indonesia. This is evident from the results of research conducted by Soeraya and Sarifah (2015) which showed that there was no difference in the effectiveness of classical music in reducing blood pressure. Traditional and murottal music has been shown to be effective in helping to lower blood pressure.

The effectiveness of traditional music therapy in reducing blood pressure in hypertensive patients is still pro and contra and there are not many results of research that supports the argument. Thus, the researchers of this academic article are interested in conducting research to examine the effectiveness of traditional music, namely Langgam Jawa music as a complementary therapy from standard hypertension therapy.

The research will be conducted at Depok II Sleman Yogyakarta Community Health Center because the number of hypertensive patients in Depok II Community Health Center has always increased. In 2016, the number of hypertensive patients increased by $38.68 \%$.

\section{MATERIALS AND METHODS}

This research used quantitative research with a type of experimental quasy used a pretest - posttest nonequivalent control group design, in which the first group was given treatment for Jawa Langgam music therapy. Before and after treatment, pretest and postest were conducted to each group to get the change data.

The population in this research were all hypertensive patients in Depok II Sleman Community Health Center. The sampling technique used in this research was accidental sampling, namely, every patients with hypertension who were found at the time of data collection. The sample in this research consisted of 60 respondents: 30 respondents for treatment group and 30 respondents for control group. Selection of samples was based on criteria including: the patients had been diagnosed with primary hypertension within the last 3 months and undergone standard hypertension treatment regularly; the patients were not suffering from an emergency hypertension; the patients were in the pre-elderly age group (45-59 years) and in elderly group (> 60 years) and; the patients were willing to become respondents.

Data collection was carried out at Depok II Community Health Center, specifically when respondents conducted health checks at the Community Healath Center. After agreeing to be a respondent, the blood pressure of respondents in treatment group was measured before intervention was given. After that, the respondents were asked to lie down and listen to the specified Langgam Jawa music by using the headset for 20 minutes. After 20 minutes, the blood pressure of the respondents was measured (post-treatment). In the control group, the blood pressure of respondents in control group was measured first. After that, the respondents were asked to take a rest for 20 minutes. Then, the blodd pressure was measured again after the respondents finished taking a rest. Blood pressure measurement was conducted using Mercury Sphygmomanometer.

Data analysis techniques in this research were carried out through univariate analysis and bivariate analysis. Before univariate and bivariate analysis, the data normality test and homogeneity test were carried out. Data normality test for each group was conducted using Kolmogorov-Smirnov because the number of samples was $>50$ subjects. If $p$-value was $>0.05$, then the data was said to be normally distributed. And if $p$-value was $<0.05$, then the data was said to be abnormally distributed. While the homogeneity test was carried out with Levene's test. If $p$-value was $>0.05$, then 
the data was said to be homogeneous. On the other hand, if $p$-value was $<0.05$, then the data was not homogeneous.

In bivariate analysis, measurements were taken to determine the difference in blood pressure from each group, namely between Langgam Jawa music group and the control group. If the results of normality data calculations were known to be normal data distribution, parametric test was conducted. Data analysis using paired t-test with a significance level of $5 \%$ was conducted to compare the differences in blood pressure before and after treatment.

\section{RESULT AND DISCUSSION}

\section{Research results}

\section{Results}

Table1. Distribution of systolic blood pressure before music therapy in the intervention group

\begin{tabular}{llcc}
\hline Blood pressure & & $\mathrm{F}(\mathrm{n})$ & $\%$ \\
\hline Systolic & $140-159 \mathrm{mmHg}$ & 18 & 60 \\
& $>160 \mathrm{mmHg}$ & 12 & 40 \\
\hline & Total & 30 & 100 \\
\hline
\end{tabular}

Primary data source

Table 1 presents that more than half of the respondents in the intervention group had systolic blood pressure in the range of $140-159 \mathrm{mmHg}$ before the administration of music therapy.

Table 2. Distribution of diastolic blood pressure before music therapy in the intervention group

\begin{tabular}{llcc}
\hline Blood pressure & & $\mathrm{F}(\mathrm{n})$ & $\%$ \\
\hline Diastolic & $<80 \mathrm{mmHg}$ & 6 & 20 \\
& $80-89 \mathrm{mmHg}$ & 5 & 16.7 \\
& $90-99 \mathrm{mmHg}$ & 12 & 40 \\
& $>99 \mathrm{mmHg}$ & 7 & 23.3 \\
\hline & Total & 30 & 100 \\
\hline
\end{tabular}

Primary data source

Table 2 demonstrates that almost half of the respondents in the intervention group had diastolic blood pressure in the range of 90$99 \mathrm{mmHg}$ before the administration of music therapy.
Table 3. Mean value of systolic and diastolic blood pressure before music therapy in the intervention group

\begin{tabular}{lll}
\hline & Mean (s.b) & Ik 95\% \\
\hline Systolic blood pressure & 157.63 & $153.3-162.9$ \\
Diastolic blood pressure & 88.73 & $84.1-93.35$ \\
\hline
\end{tabular}

Primary data source

Based on the table 3, the data shows that the mean value of systolic blood pressure in the intervention group's respondents before the administration of music therapy was 157.63 , while the mean value of diastolic blood pressure was 88.73

Table 4. Distribution of systolic blood pressure before resting in the control group

\begin{tabular}{llcc}
\hline Blood pressure & & $\mathrm{F}(\mathrm{n})$ & $\%$ \\
\hline Systolic & $140-159 \mathrm{mmHg}$ & 23 & 76.7 \\
& $>160 \mathrm{mmHg}$ & 7 & 23.3 \\
\hline & Total & 30 & 100 \\
\hline
\end{tabular}

Primary data source

Table 4 shows that most of the control group's respondents had systolic blood pressure in the range of $140-159 \mathrm{mmHg}$ before resting.

Table 5. Distribution of diastolic blood pressure before resting in the control group

\begin{tabular}{llcc}
\hline & & $\mathrm{F}(\mathrm{n})$ & $\%$ \\
\hline Diastolic & $<80 \mathrm{mmHg}$ & 4 & 13.3 \\
\hline & $80-89 \mathrm{mmHg}$ & 1 & 3.3 \\
& $90-99 \mathrm{mmHg}$ & 17 & 56.7 \\
& $>99 \mathrm{mmHg}$ & 8 & 26.7 \\
\hline & Total & 30 & 100 \\
\hline
\end{tabular}

Primary data source

According table 5, more than half of the control group's respondents had diastolic blood pressure in the range of $90-99 \mathrm{mmHg}$ before resting.

Table 6. Mean value of systolic and diastolic blood pressure before resting in the control group

\begin{tabular}{lcc}
\hline & Mean (s.b) & lk 95\% \\
\hline Systolic blood pressure & 149,667 & $144,47-154,85$ \\
Diastolic blood pressure & 90,5 & $86,4-94,55$ \\
\hline
\end{tabular}

Primary data source 
Table 6 presents that the mean value of systolic blood pressure in the control group before resting was $149,667 \mathrm{mmHg}$, while the mean value of diastolic blood pressure was 90,5 $\mathrm{mmHg}$.

Table 7. Distribution of systolic blood pressure after music therapy in the intervention group

\begin{tabular}{llcc}
\hline Blood pressure & & $\mathrm{F}(\mathrm{n})$ & $\%$ \\
\hline Systolic & $120-139 \mathrm{mmHg}$ & 6 & 20 \\
& $140-159 \mathrm{mmHg}$ & 16 & 53.3 \\
& $>160 \mathrm{mmHg}$ & 8 & 26.7 \\
\hline & Total & 30 & 100 \\
\hline
\end{tabular}

Primary data source

Table 7 demonstrates that more than half of the respondents in the intervention group had systolic blood pressure in the range of 140-159 $\mathrm{mmHg}$ after the administration of music therapy.

Table 8. Distribution of diastolic blood pressure after music therapy in the intervention group

\begin{tabular}{llcc}
\hline Blood pressure & & $\mathrm{F}(\mathrm{n})$ & $\%$ \\
\hline Diastolic & $<80 \mathrm{mmHg}$ & 10 & 33.3 \\
& $90-99 \mathrm{mmHg}$ & 10 & 33.3 \\
& $>99 \mathrm{mmHg}$ & 10 & 33.3 \\
\hline & Total & 30 & 100 \\
\hline
\end{tabular}

Primary data source

Based on the table 8, it was found that less than half of the respondents in the intervention group had diastolic blood pressure in the range of $90-99 \mathrm{mmHg}$ after the administration of music therapy.

Table 9. Mean value of systolic and diastolic blood pressure after music therapy in the intervention group

\begin{tabular}{lll}
\hline & Mean (s.b) & Ik 95\% \\
\hline Systolic blood pressure & $148.9 \mathrm{mmHg}$ & $144.2-153.7$ \\
Diastolic blood pressure & $83.37 \mathrm{mmHg}$ & $79.2-87.5$ \\
\hline
\end{tabular}

Primary data source
Table 10. Distribution of systolic blood pressure after resting in the control group

\begin{tabular}{llcc}
\hline Blood pressure & & $\mathrm{F}(\mathrm{n})$ & $\%$ \\
\hline Systolic & $120-139 \mathrm{mmHg}$ & 6 & 20 \\
& $140-159 \mathrm{mmHg}$ & 16 & 53.3 \\
& $>160 \mathrm{mmHg}$ & 8 & 26.7 \\
\hline & Total & 30 & 100 \\
\hline
\end{tabular}

Primary data source

Table 11. Distribution of diastolic blood pressure after resting in the control group

\begin{tabular}{llcc}
\hline Blood pressure & & $\mathrm{F}(\mathrm{n})$ & $\%$ \\
\hline Diastolic & $<80 \mathrm{mmHg}$ & 0 & 0 \\
& $80-89 \mathrm{mmHg}$ & 6 & 20 \\
& $90-99 \mathrm{mmHg}$ & 16 & 53.3 \\
& $>99 \mathrm{mmHg}$ & 8 & 26.7 \\
\hline & Total & 30 & 100
\end{tabular}

Primary data source

According table 9, the mean value of systolic blood pressure in the intervention group after the administration of music therapy was $148.9 \mathrm{mmHg}$, and the mean value of diastolic blood pressure was $83.37 \mathrm{mmHg}$.

Table 10 shows that more than half of the control group's respondents had systolic blood pressure in the range of $140-159 \mathrm{mmHg}$ after the administration of music therapy.

Table 11 founded that more than half of the control group's respondents had diastolic blodd pressure in the range of $90-99 \mathrm{mmHg}$ after resting.

Table 12. Mean value of systolic and diastolic blood pressure after resting in the control group

\begin{tabular}{lll}
\hline & Mean (s.b) & Ik 95\% \\
Systolic blood pressure & $148.66 \mathrm{mmHg}$ & $142,63-154,69$ \\
Diastolic blood pressure & $89,23 \mathrm{mmHg}$ & $85,54-92,9$ \\
Primary data source & &
\end{tabular}

Table 13. Difference in mean value of systolic and diastolic blood pressure before and after the administration of music therapy in the intervention group

\begin{tabular}{lllll}
\hline & \multicolumn{2}{c}{ Before therapy } & \multicolumn{2}{c}{ After therapy } \\
\hline & Mean (s.b) & Ik 95\% & Mean (s.b) & Ik 95\% \\
\hline Systolic blood pressure & 157.63 & $153.3-162.9$ & $148.9 \mathrm{mmHg}$ & $144.2-153.7$ \\
Diastolic blood pressure & 88.73 & $84.1-93.35$ & 83.37 & $79.2-87.5$ \\
\hline
\end{tabular}

Primary data source 
Table 14. Difference in mean value of systolic and diastolic blood pressure before and after resting in the control group

\begin{tabular}{lcccc}
\hline & \multicolumn{2}{c}{ Before therapy } & \multicolumn{2}{c}{ After therapy } \\
\hline & Mean (s.b) & $\mathrm{Ik} 95 \%$ & Mean (s.b) & $\mathrm{Ik} 95 \%$ \\
\hline Systolic blood pressure & 149,667 & $144,47-154,85$ & $148,67 \mathrm{mmHg}$ & $142,63-154,69$ \\
Diastolic blood pressure & 90,5 & $86,4-94,55$ & 89,23 & $85,54-92,9$ \\
\hline
\end{tabular}

Primary data source

Table 15. Results of analysis by pair $t$ test in the intervention group

\begin{tabular}{lcccc}
\hline & Mean (s.b) & Difference (s.b) & Ik 95\% & p value \\
\hline Systolic BP before therapy & $157.63(14.27)$ & $8.67(10.17)$ & $4.86-12.46$ & 0.000 \\
Systolic BP after therapy & $148.97(12.74)$ & & & \\
\hline
\end{tabular}

Primary data source

Table 16. Results of analysis by pair $t$ test in the intervention group

\begin{tabular}{lcccc}
\hline & Mean (s.b) & Difference (s.b) & Ik 95\% & p value \\
\hline Diastolic BP before therapy & $88.73(12.37)$ & $5.37(7.07)$ & $2.73-8.0$ & 0.000 \\
Diastolic BP after therapy & $83.37(11.16)$ & & & \\
\hline
\end{tabular}

Primary data source

Table 17. Results of analysis by pair $\mathbf{t}$ test in the control group

\begin{tabular}{lcccc}
\hline & Mean (s.b) & Difference (s.b) & Ik 95\% & p value \\
\hline Systolic BP before therapy & $149,667(13,89)$ & $5,95(1,08))$ & $1,22-3,22$ & 0.365 \\
Systolic BP after therapy & $148.67(16,14)$ & & & \\
\hline
\end{tabular}

Primary data source

Table 18. Results of analysis by pair $t$ test in the control group

\begin{tabular}{lcccc}
\hline & Mean (s.b) & Difference (s.b) & lk 95\% & p value \\
\hline Dyastolic BP before therapy & $90,5(10,85)$ & $1,26(7,48))$ & $1,52-4.06$ & 0.362 \\
Dyastolic BP after therapy & $89,23(9,88)$ & & & \\
\hline
\end{tabular}

Primary data source

Based on the table 12, it was found that the mean value of systolic blood pressure after resting in the control group was $148.66 \mathrm{mmHg}$, and the mean value of diastolic blood pressure was $89,23 \mathrm{mmHg}$.

Table 13 presents that there are differences in the mean value of systolic and distolic blood pressure before and after the administration of music therapy in the intervention group.

Table 14 demontrates that there are differences in the mean value of systolic and diastolic blood pressure in the control group.

Table 15 shows that there are differences in the results of systolic blood pressure before and after music therapy in the intervention group as evidenced by the $p$ value of 0.000 .

According table 16, there are differences in the results of diastolic blood pressure before and after music therapy in the intervention group as evidenced by the $p$ value of 0.000 .

Based on the table 17, there were no differences in the results of systolic blood pressure before and after resting in the control group as evidenced by the $p$ value of 0.365 .

Table 18 presents that there were no differences in the results of diastolic blood pressure before and after resting in the control group as evidenced by the $p$ value of 0.362 


\section{Discussion}

Blood Pressure Before The Administration of Langgam Jawa Music Therapy

The results showed that the highest value of systolic blood pressure in the intervention and control group was $205 \mathrm{mmHg}$ and 200 $\mathrm{mmHg}$, while the highest diastolic value in the intervention group and the control group was $110 \mathrm{mmHg}$ and $100 \mathrm{mmHg}$. The blood pressure of the hypertension respondents in the intervention group and the control group tended to be high, even though the respondents had taken routine blood pressure drugs such as Amlodipine $10 \mathrm{mg}$. Increase in blood pressure in hypertensive patients occured even though they have taken routine antihypertensive drugs was caused by several things. The results of research conducted by Jannah, Nurhasanah, Azmi \& Sartika (2017) showed that the causes of the increase in blood pressure in hypertensive patients were mostly caused by age, sex, stress and smoking. According to Jannah, Nurhasanah, Azmi \& Sartika (2017), sex factors had a relationship with an increase in blood pressure, which supported the results of research who showed that the total male sufferers who had increased blood pressure were 18 respondents (30\%) of the total intervention group's and control group's respondents. This was due to unhealthy behaviors such as unbalanced eating patterns that caused an increase in body weight which often carried out by female sufferers (5).

Most of the respondents who were classified in elderly population, was also one of the supporting factors for the tendency of increased blood pressure values despite taking anti-hypertensive drugs. The aging process experienced by the elderly resulted in blood vessel stiffness as a result of decreased blood vessel elasticity. Stiffness of the blood vessels resulted in failure of vasodilation resulting in hypertension (3). Blood pressure that tended to be high in hypertensive patients even though they regularly consume anti-hypertensive drugs was also influenced by the duration of hypertension. The longer the time the patients were suffering from hypertension, the coping mechanism was increasingly adaptive and the stress level also decreased. Therefore, in long-term hypertensive patients, blood pressure tended to be stable while consuming anti-hypertensive drugs (1).

\section{Blood Pressure After The Administration of Langgam Jawa Music Therapy}

The results showed that, blood pressure in the intervention group after given Javanese style music therapy tended to decrease, with a decrease in blood pressure values of $4.4 \mathrm{mmHg}$. These results were compared to blood pressure values in the control group, where there were no differences in blood pressure before and after rest

The type of Langgam Jawa used in this research was Keroncong music (Hardjana, 2008) with Waljinah as the singer. Keroncong music is indeed very familiar to the ear, especially when coupled with the sound of the singer, Waljinah, who has a characteristic that makes the Keroncong music is increasingly preferred, especially in the elderly in Java, especially in Sleman Regency. Traditional music is one type of relaxation music, this is also evidenced in a research conducted by Shimizu et al (2013) showing that traditional Japanese music, Naruko music, has been shown to reduce systolic blood pressure. The research on traditional music was also conducted by Bekiroglu, Ovayolu., Ergun; Hasan, Ekerbic (2013). The results showed that traditional Turkish music was effective in reducing diastolic blood pressure.

Another research that also used traditional music was Lengga, Mediani, Purba (2016) which used traditional Sundanese music. Lengga, Mediani, Purba (2016) compared the 
effectiveness of classical music, traditional Sundanese music and Murottal music. The results showed that Sundanese traditional music significantly lowered blood pressure. The results of research conducted by Lengga, Mediani, Purba (2016) recommended that traditional music can be an option to reduce blood pressure.

\section{Difference of Blood Pressure Mean Value Before and After The Administration of Langgam Jawa Music Therapy}

The results showed that the difference in the mean value of blood pressure before and after the administration of Langgam Jawa music therapy was decrease for systolic and diastolic blood pressure. The results of the research showed that after the administration of a 15-minute break in control group, the blood pressure tended to increase. The results of this research were also in accordance with the results of research conducted by Liu \& Petrini (2015). The results of the research conducted by Liu \& Petrini (2015) on 51 control groups who were only given standard therapy and resting, compared to the intervention group who was given standard therapy and soft music for 30 minutes in 3 days, showed that there was no decrease in systolic and diastolic blood pressure values. The same intervention in the control group was also carried out by Beaulieu et al (2013) who was not given classical music. Effectiveness was assessed through blood cortisol values. The results of the research conducted by Beaulieu et al (2013) showed that there was no decrease in blood cortisol. In fact, there was an increase in blood cortisol in groups that were not given classical music and were only given a time for rest. There are many factors that affect whether or not the blood pressure or blood cortisol experienced an increase due to differences in psychological conditions, adaptation period for sleeping/ resting in a strange place, and the possibility of respondents having different perceptions because they have to wait a long time so that they affect the feeling of comfort.

However, different findings were found in the case group. The results showed that there were differences in the mean systolic and diastolic blood pressure between before and after the administration of music therapy in the case group. Langgam Jawa music therapy used in the study was the type of keroncong. Keroncong was very familiar and popular in Java, especially in Yogyakarta, so that type of music is perceived easily by respondents and results comfort. The comfort felt by the respondents triggers an increase in endorphins and encephalins resulting in a decrease in catecholamines which affects a decrease in blood pressure. The perceived comfort of the respondent results relaxation so that the heart rate, breathing of the body becomes maximal. This process has an effect on the relaxation of blood vessels so that blood pressure decreases to normal or stable limits (7). Listening to Langgam Jawa music produced relaxation so that it could activate soluble Guanylyl Cyclase (sGC) so as to increase the level of nitric oxcide (NO). Relaxation was also able to predict respondents' hemodynamics, relaxation conditions also restore the body's heart rate and breathing back to normal, so that oxygen in the body was fulfilled (14). Langgam Jawa music therapy was used as adjuvant therapy in the research plan in Depok II Community Health Center because it was in accordance with the culture and habits of the respondents, most of which were familiar with Javanese culture, which was expected to increase the effectiveness of standard therapy so that blood pressure can be controlled.

\section{CONCLUSION AND RECOMMENDATION}

There is the effect of Langgam Jawa music therapy on changes in blood pressure in elderly people who are suffering from hypertension (p 0.000). Langgam Jawa music therapy can 
be one of the options for adjuvant therapy to control blood pressure which can be done in the service unit closest to the community, namely the Community Health Center. In addition, it can be used in the target areas of the Community Health Center, namely the Integrated Service Station for elderlies (Posyandu Lansia) through Posyandu administrators.

\section{REFERENCES}

1. Adriyanto, A. \& Santoso, W. (2015). Hubungan antara derajat hipertensi dengan mekanisme koping penderita hipertensi. Jurnal Penelitian Kesehatan, 12 (2), 1-13.

2. Beaulieu-Boire, G., Bourque, S., Chagnon, F., Chouinard, L., Gallo-Payet, N., \& Lesur, O. (2013). Music and biological stress dampening in mechanically-ventilated patients at the intensive care unit ward-A prospective international randomized crossover trial. Journal of Critical Care, 28, 442-452

3. Fukutomi, M. \& Kario, K. (2010). Aging and hypertension. Expert Review Cardiovascular, 11 (8), 1531-1539. Hardjana, S. (2008). Menggugat Republik Keroncong. Bandung: Gedung Indonesia Menggugat.

4. James et al. (2014). Evidence-based guideline for the management of high blood pressure in adults (JNC 8). JAMA.; 31 (5) 507-520.

5. Jannah, M., Nurhasanah., Azmi, N., \& Sartika, R.A. (2017). Analisis faktor penyebab kejadian hipertensi di wilayah kerja puskesmas mangasa kecamatan tamalate makassar. Jurnal PENA|Volume 3|Nomor 1 |ISSN 2355-3766|410

6. Jurcau, R., \& Jurcau, I. (2011). Influence of music therapy on anxety and salivary cortisol in stress induced by short term intense physical exercise. Palestrica of the Third Millenium-Civilzation and Sport, 13(4), 321-325.
7. Kolcaba, K., Tilton, C., \& Drouin, C. (2006). Comfort theory. The Journal of Nursing Administration, 36 (11), 538-544

8. Liu, Y. \& Petrini, M.A. (2015). Effects of music therapy on pain, anxiety, and vital signs in patientsafter thoracic surgery. Elsevier, 23 (1), 714-718.

9. Loomba, R.,Shah, P.H., Chndrasekar, S., Arora, R\& Molnar, J. (2012). Effect of Hagins, M., Rundle, A., Consedine, N., \& Khalsa, S.B. (2014). A randomized controlled trial comparing the effects of yoga with an active control on ambulatory blood pressure in inviduals with prehypertension. The Journal Of Clinical Hypertension, 6 (1), 54-62.

10. Manandhar, K., Roju, R., Sinha, N.P., Humagain, S. (2012). Prevalence and associated risk factors of hypertension among people aged 50 years and more in Banepa Municipality, Nepal. Kathmandu University Medical Jornal. Vol 10(3), 35-38

11. Morton, P.G., Fontaine, D., Hudak, C.M., \& Gallo, B.M. (2013). Keperawatan kritis Pendekatan Holistik. Volume 1. Edisi 8. Diterjemahkan oleh Subekti, N.B., Nurwahyu., Mardella, E.A., \&Karyuni, P.E. Jakarta: EGC.

12. Muhadi. (2016). JNC 8: Evidence based guideline penanganan pasien hipertensi dewasa. CDK-36. Vol 1 no 1.

13. Okada, L., Kurita, A., Takase, B., Otsuka, T., Kodani, E., Kusama, Y., Atarashi, H., \& Mizuno, K. (2008). Effect of music therapy on autonomic nervous system activity, incidence of heart failure events and plasma cytokine and cathecolamine levels in elderly patinets with cerebrovascular disease and dementia. International Heart Jornal, 50(1), 95-110.

14. Rodrigues, G.J., Cicillini, S.A., Silva, R.S., \& Benhack, L.M. (2011). Mechanisms underlying the vascular relaxation induced by a new nitric oxide generator. Elsevier, 25, 331-337. 
15. Siritunga, S., Wijewardena,K., Ruwan, E., \& Mudunkotuwa, P. (2013). Effect of music on blood pressure, pulse rate and respiratory rate of asymptomatic individuals: a randomized controlled trial. Health, vol 5 no $4 A, 59-64$.
16. Soeraya, L.A., \&Sarifah, S. (2015). Pengaruh terapi musik keroncong terhadap tingkat depresi pada lansia. Profesi, vol 13 (1), 5255. 